\title{
Metabolism of 2-Oxoaldehydes in Bacteria: Purification and Characterization of Methylglyoxal Reductase from Escherichia coli
}

\author{
Toshihiko SaIkusa, Hae-ik Rhee, Kunihiko Watanabe, \\ Kousaku Murata and Akira Kimura \\ Research Institute for Food Science, Kyoto University, \\ Uji, Kyoto 611, Japan \\ Received January 19, 1987
}

\begin{abstract}
The activities of 2-oxoaldehyde-metabolizing enzymes (glyoxalase I, glyoxalase II, methylglyoxal reductase, methylglyoxal dehydrogenase and lactaldehyde dehydrogenase) were found to be widely distributed among microorganisms. One of the enzymes, methylglyoxal reductase, which catalyzes the reductive conversion of methylglyoxal into lactaldehyde, was purified from Escherichia coli cells. The enzyme was judged to be homogeneous on polyacrylamide gel electrophoresis and was a monomer with a molecular weight of 43000 . The enzyme was most active at $\mathrm{pH} 6.5$ and $45^{\circ} \mathrm{C}$. The enzyme utilized both NADPH and NADH for the reduction of 2oxoaldehydes (glyoxal, methylglyoxal, phenylglyoxal and 4,5-dioxovalerate) and some aldehydes (glycolaldehyde, D,L-glyceraldehyde, propionaldehyde and acetaldehyde). The $\mathrm{Km}$ values of the enzyme for methylglyoxal, NADPH and NADH were $4.0 \mathrm{~mm}, 1.7 \mu \mathrm{M}$ and $2.8 \mu \mathrm{m}$, respectively. The product of methylglyoxal reduction was identified as lactaldehyde. The enzyme from $E$. coli cells was different from the yeast and goat liver enzymes in both molecular structure and substrate specificity.
\end{abstract}

Methylglyoxal, a typical biological 2-oxoaldehyde, is a toxic compound, that is synthesized from either dihydroxyacetonephosphate through the action of methylglyoxal synthase [EC 4.2.99.11] or aminoacetone through the action of monoamine oxidase [EC 1.4.3.4]. In the course of a study on the metabolic fate of methylglyoxal in Saccharomyces cerevisiae cells, we found a novel enzymatic route for the conversion of the ketoaldehyde. ${ }^{1,2)}$ Through this route, methylglyoxal was converted into lactate via lactaldehyde through consecutive enzyme reactions catalyzed by methylglyoxal reductase and lactaldehyde dehydrogenase. The origin of lactaldehyde in yeast cells has been definitely identified by the finding of methylglyoxal reductase. ${ }^{11}$

Recently, methylglyoxal reductase was also isolated from goat liver by Ray and Ray. ${ }^{3)}$ However, the reductase in goat liver greatly differs from that in yeast cells in both molecular weight and substrate specificity. To com- pare the properties of the reductases systematically, we here purified methylglyoxal reductase from Escherichia coli and showed that E. coli cells contained two kinds of methylglyoxal reductases, that are different from the yeast and goat liver enzymes.

\section{MATERIALS AND METHODS}

Chemicals. Methylglyoxal and S-lactoylglutathione were purchased from Sigma Chemical Co., St. Louis, MO. 4,5-Dioxovalerate was prepared from 3,5-dibromolevulinate, which was also from Sigma, by the method of Varticovski et al. ${ }^{4)}$ L-Lactaldehyde was prepared from Lthreonine according to Huff and Rudney. ${ }^{5)}$ Yeast extract, Bacto peptone and malt extract were from Nakarai Chemical Co., Ltd., Kyoto, Japan.

Cultivation of microorganisms. The media used for the cultivation of microbial cells were as follows: (for bacteria) $0.1 \%$ glucose, $1.0 \%$ yeast extract, $0.5 \%$ Bacto peptone, $0.5 \% \mathrm{NaCl}, \mathrm{pH} 7.2$; (for streptomyces) $0.4 \%$ glucose, $1.0 \%$ malt extract, $0.4 \%$ yeast extract, $\mathrm{pH} 7.5$; (for molds) $2.0 \%$ malt extract, $0.1 \%$ Bacto peptone, $2.0 \%$ glucose (tap 
water); and (for yeasts) $2.0 \%$ glucose, $1.0 \%$ yeast extract, $2.0 \%$ Bacto peptone, $\mathrm{pH}$ 5.0. All the organisms were cultivated in $100 \mathrm{ml}$ of medium (in $5 \mathrm{dl}$ Sakaguchi flasks) at $30^{\circ} \mathrm{C}$ with reciprocation $(120 \mathrm{rpm})$ for $10 \mathrm{hr}$.

Preparation of cell extracts. The cells were harvested, washed once with a chilled $0.85 \%$ saline solution and then resuspended in $10 \mathrm{~mm}$ Tris $-\mathrm{HCl}$ buffer $(\mathrm{pH}$ 7.0). The bacterial cells were sonicated at $90 \mathrm{kHz}$ for $5 \mathrm{~min}$ at $0^{\circ} \mathrm{C}$. Other cells were homogenized with a Brown homogenizer for $1 \mathrm{~min}$ at $0^{\circ} \mathrm{C}$. The sonicates and homogenates were centrifuged at $25,000 \times g$ for $30 \mathrm{~min}$ and then the resulting supernatants were used for the enzyme assays after dialysis against $10 \mathrm{~mm}$ Tris- $\mathrm{HCl}$ buffer $\left(\mathrm{pH} \mathrm{7.0)}\right.$ at $4^{\circ} \mathrm{C}$ overnight.

Enzyme assays. The assays for glyoxalase $\mathrm{I},{ }^{6)}$ glyoxalase II, ${ }^{7)}$ methylglyoxal reductase, ${ }^{1)}$ lactaldehyde dehydrogenase $^{2)}$ and methylglyoxal dehydrogenase ${ }^{8)}$ were performed according to the methods described previously. The assay mixture for methylglyoxal reductase contained $10 \mathrm{~mm}$ methylglyoxal, $0.15 \mathrm{~mm}$ NADPH, $100 \mathrm{~mm}$ Tris $-\mathrm{HCl}$ buffer $(\mathrm{pH} 7.0)$ and the enzyme in a volume of $1.0 \mathrm{ml}$. The reaction was initiated by adding the enzyme, and the decrease in the absorbance at $340 \mathrm{~nm}$ was recorded with a Hitachi Spectrophotometer Model 100 at $25^{\circ} \mathrm{C}$. The specific activity was expressed as $\mu \mathrm{mol}$ of NADPH oxidized per mg of protein per min. Protein was determined by the method of Lowry et al. ${ }^{9}$ )

\section{Purification of methylglyoxal reductase}

(1) Cell extracts. Escherichia coli IFO 3806 cells were cultivated under the conditions described above. The cells ( $100 \mathrm{~g}$ wet wt.) from a $10 \mathrm{l}$ culture were washed once with a chilled $0.85 \%$ saline solution, resuspended in $10 \mathrm{~mm}$ Tris$\mathrm{HCl}$ buffer ( $\mathrm{pH} \mathrm{7.0)}$ and then sonicated at $90 \mathrm{kHz}$ for $5 \mathrm{~min}$ at $0^{\circ} \mathrm{C}$. The sonicates were centrifuged at $25,000 \times g$ for 30 min and then the clear supernatants obtained were used for purification of the enzyme.

(2) DEAE-Cellulose column chromatography. The cell extracts $(470 \mathrm{ml}, 3,550 \mathrm{mg}$ protein) was applied to a DEAE-cellulose column $(5.5 \times 50 \mathrm{~cm})$ equilibrated with $10 \mathrm{~mm}$ Tris- $\mathrm{HCl}$ buffer $(\mathrm{pH} 7.0)$ and then the enzyme was eluted with an increasing linear gradient of $\mathrm{KCl}$, from 0 to $1.0 \mathrm{M}$, in the same buffer. The flow rate was $13 \mathrm{ml} /$ tube/ $5 \mathrm{~min}$. The active fractions, which were eluted when the conductivity was approximately $10 \sim 20 \mathrm{m \mho}$, were collected.

(3) Butyl Toyopearl 650M hydrophobic column chromatography. The enzyme solution $(320 \mathrm{ml}, 1,290 \mathrm{mg}$ protein) was saturated with ammonium sulfate $(30 \%)$ and then the precipitated materials were removed by centrifugation. The precipitates showed no enzyme activity. The supernatants were applied to a Butyl Toyopearl $650 \mathrm{M}$ column $(4.2 \times 16 \mathrm{~cm})$ equilibrated with $30 \%$ ammonium sulfate in $10 \mathrm{~mm}$ Tris- $\mathrm{HCl}$ buffer ( $\mathrm{pH}$ 6.5). The enzyme was eluted with a decreasing linear gradient of ammonium sulfate, from 30 to $0 \%$, in the same buffer. The flow rate was
$6.0 \mathrm{ml} / \mathrm{tube} / 3 \mathrm{~min}$. The active fractions, that were eluted at about 5 to $0 \%$ ammonium sulfate, were pooled, concentrated by ultrafiltration on an Amicon PM10 membrane and then dialyzed against $10 \mathrm{~mm}$ Tris- $\mathrm{HCl}$ buffer (pH 7.0) at $4{ }^{\circ} \mathrm{C}$ overnight.

(4) Sephadex G-150 column chromatography. The dialysate $(75 \mathrm{ml}, 67.5 \mathrm{mg}$ protein) was put onto a Sephadex G-150 column $(2.5 \times 85 \mathrm{~cm})$ equilibrated with $10 \mathrm{~mm}$ Tris- $\mathrm{HCl}$ buffer $(\mathrm{pH} 7.0)$ and then the enzyme was eluted with the same buffer at a flow rate of $4.6 \mathrm{ml} /$ tube/ $10 \mathrm{~min}$. The active fractions (Fr. Nos. $45 \sim 60$ ) were combined.

(5) Hydroxylapatite column chromatography. The pooled fractions $(50 \mathrm{ml}, 51 \mathrm{mg}$ protein) were applied to a hydroxylapatite column $(1 \times 10 \mathrm{~cm})$ equilibrated with $10 \mathrm{~mm}$ potassium phosphate buffer $(\mathrm{pH} 7.0)$ and then the enzyme was eluted with an increasing linear gradient of the buffer from 10 to $500 \mathrm{~mm}$. Fractions were collected at $0.9 \mathrm{ml} /$ tube $/ 7 \mathrm{~min}$. The active fractions, which were eluted at $10 \mathrm{~mm}$ to $20 \mathrm{~mm}$ buffer, were pooled, concentrated to about $2 \mathrm{ml}$ as above and then dialyzed against $10 \mathrm{~mm}$ Tris$\mathrm{HCl}$ buffer $(\mathrm{pH} 7.0)$ at $4{ }^{\circ} \mathrm{C}$ overnight.

Gel filtration. The molecular weight of the enzyme was determined by gel filtration on a Sephadex G-150 column $(1 \times 90 \mathrm{~cm})$ equilibrated with $10 \mathrm{~mm}$ Tris- $\mathrm{HCl}$ buffer $(\mathrm{pH}$ 7.0). All the proteins were eluted with the same buffer at a flow rate of $2 \mathrm{ml} /$ tube/ $7 \mathrm{~min}$.

Polyacrylamide gel electrophoresis. Polyacrylamide gel electrophoresis in the presence or absence of sodium dodesyl sulfate (SDS) was performed according to Laemmli. $^{10)}$

\section{RESULTS}

Distribution of 2-oxoaldehyde-metabolizing enzyme activities among microbial cells

The distribution of enzyme activities involved in 2-oxoaldehyde metabolism was investigated among various microbial cells (Table I). The enzyme activities in the glyoxalase system (glyoxalase I and glyoxalase II) and the reduction/oxidation route (methylglyoxal reductase and lactaldehyde dehydrogenase) were found in all the microbial cells tested. Methylglyoxal dehydrogenase activity was found only in Pseudomonas putida cells. ${ }^{8)}$ The methylglyoxal reductase activity, in question, was high in Escherichia coli IFO 3806, Bacillus subtilis IFO 3026, B. subtilis IFO 3027 and Saccharomyces cerevisiae IFO 0641. E. coli IFO 3806 was chosen as the source of methylglyoxal reductase for the purification. 
TABle I. Distribution of 2-OxOAldehyde-Metabolizing EnZyme ACtivities among Microorganisms

\begin{tabular}{|c|c|c|c|c|c|}
\hline \multirow{2}{*}{ Strains } & \multicolumn{5}{|c|}{ Activity (nmol/min/mg protein) } \\
\hline & $\begin{array}{c}\text { Glyoxalase } \\
\text { I }\end{array}$ & $\begin{array}{c}\text { Glyoxalase } \\
\text { II }\end{array}$ & $\begin{array}{l}\text { Methylglyoxal } \\
\text { reductase }\end{array}$ & $\begin{array}{l}\text { Methylglyoxal } \\
\text { dehydrogenase }\end{array}$ & $\begin{array}{l}\text { Lactaldehyde } \\
\text { dehydrogenase }\end{array}$ \\
\hline Escherichia coli IFO 3806 & 12 & 10 & 130 & 0 & 0.45 \\
\hline Escherichia coli $\mathrm{K}-12$ & 5.7 & 58 & 26 & 0 & 0.23 \\
\hline Escherichia coli $\mathrm{C} 600$ & 10 & 43 & 87 & 0 & 0.34 \\
\hline Bacillus subtilis IFO 3009 & 11 & 37 & 21 & 0 & $\mathrm{t}$ \\
\hline Bacillus subtilis IFO 3026 & 9.1 & 62 & 98 & 0 & 0.67 \\
\hline Bacillus subtilis IFO 3027 & 13 & 45 & 87 & 0 & 0.13 \\
\hline Pseudomonas putida IFO 3738 & 37 & 21 & 32 & 110 & Not tested \\
\hline Pseudomonas aeruginosa IFO 3080 & 13 & 9.8 & 13 & 0 & 0.23 \\
\hline Pseudomonas fluorescens IFO 3903 & 22 & 17 & 43 & 0 & 0.90 \\
\hline Streptomyces coellicolor IFO 3176 & 23 & 9.4 & 13 & 0 & 1.2 \\
\hline Streptomyces aureofaciens IFO 3305 & 19 & 21 & 9.6 & 0 & 0.96 \\
\hline Streptomyces griseus IFO 3102 & 28 & 34 & 54 & 0 & 0.78 \\
\hline Mucor javanicus IFO 4570 & 99 & 23 & 14 & 0 & 3.26 \\
\hline Mucor javanicus IFO 4572 & 74 & 32 & 11 & 0 & 3.28 \\
\hline Aspergillus sojae IFO 4274 & 32 & 45 & 35 & 0 & 2.36 \\
\hline Saccharomyces cerevisiae IFO 0641 & 240 & 48 & 110 & 0 & 5.7 \\
\hline Saccharomyces carlsbergensis IFO 0751 & 260 & 52 & 83 & 0 & 6.4 \\
\hline Saccharomyces rouxii IFO 0505 & 190 & 68 & 73 & 0 & 3.8 \\
\hline
\end{tabular}

The activities of all the enzymes were determined as described under MATERIALS AND METHODS.

Purification of methylglyoxal reductase from $E$. coli

Methylglyoxal reductase activity was eluted as a single peak on DEAE-cellulose column chromatography (Fig. 1A) and on Butyl Toyopearl column chromatography at $\mathrm{pH} 7.5$ (Fig. 1B). However, the activity was separated into two peaks (Peaks I and II) on Butyl Toyopearl hydrophobic column chromatography, when the column was operated at slightly acidic $\mathrm{pH}(\mathrm{pH}$ 6.5 7.0) (Figs. 1C and $\mathrm{D})$. With a decrease in the elution $\mathrm{pH}$, the Peak II activity decreased with an increase in the Peak I activity, and the elution position of the Peak II enzyme was shifted to a more hydrophobic region. The Butyl Toyopearl column was operated at $\mathrm{pH} \mathrm{6.5,} \mathrm{and} \mathrm{Peak} \mathrm{II}$ enzyme was purified further. The Peak II enzyme was found to be considerably unstable during the purification procedures. Little protection of the enzyme from inactivation was seen on the addition of glycerol $(30 \%)$, ethylenediaminetetraacetate (EDTA,
$1.0 \mathrm{~mm}), 2$-mercaptoethanol $(0.2 \mathrm{~mm})$ or a mixture of them. The overall purification procedures for the Peak II enzyme are summarized in Table II. The enzyme was purified approximately 50 -fold with a $6 \%$ activity yield. The purified enzyme was judged to be homogeneous on polyacrylamide gel electrophoresis in the absence (data not shown) and presence of SDS (Fig. 2B).

\section{Molecular weight of methylglyoxal reductase}

The molecular weight of the methylglyoxal reductase (Peak II enzyme) was estimated to be 42,000 by gel filtration on a Sephadex G150 column (Fig. 2A). A closely similar value $(43,000)$ was obtained on SDS/polyacrylamide gel electrophoresis (Fig. 2B), indicating that the purified methylglyoxal reductase was a monomer with a molecular weight of $42,000 \sim 43,000$.

\section{Properties of methylglyoxal reductase}

(1) Effects of $p H$ and temperature. The en- 
Table II. Summary of the Purification of Methylglyoxal Reductase

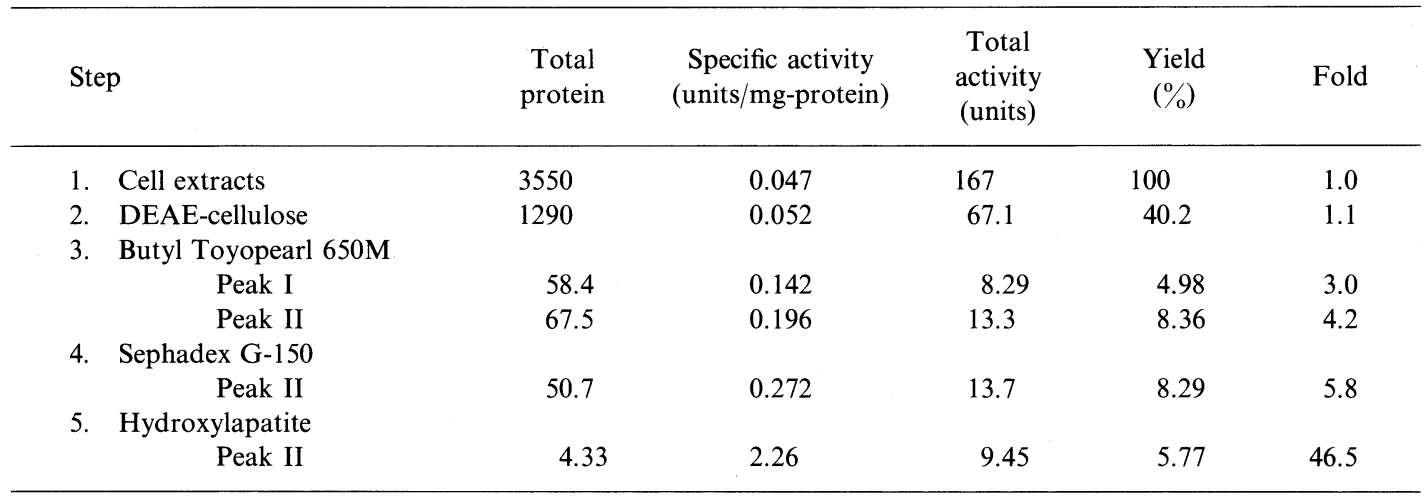

The purification procedures were as described under Materials AND Methods.

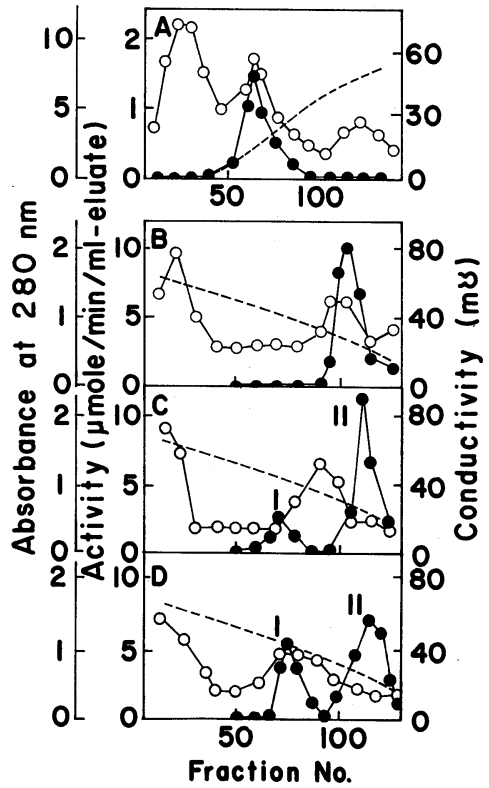

FIG. 1. Elution Patterns of Methylglyoxal Reductase on DEAE-Cellulose (A) and Butyl Toyopearl (B, C and D) Columns.

The conditions for the column chromatographies were given under Materials and Methods. The Butyl Toyopearl columns were operated using $10 \mathrm{~mm}$ Tris- $\mathrm{HCl}$ buffer of various $\mathrm{pHs}(\mathrm{B}, \mathrm{pH} 7.5 ; \mathrm{C}, \mathrm{pH} 7.0$; and $\mathrm{D}, \mathrm{pH}$ 6.5). - $\mathrm{O}-$, absorbance at $280 \mathrm{~nm} ;-\mathrm{O}-$, activity; ------, conductivity.

zyme was most active at $\mathrm{pH} 6.5$ and $40^{\circ} \mathrm{C}$. The enzyme showed $50 \%$ activity at $\mathrm{pH} 4.5$ (sodium acetate buffer) or 9.5 (glycine- $\mathrm{KOH}$ buffer), and at $25^{\circ} \mathrm{C}$ or $75^{\circ} \mathrm{C}$ (data not shown).

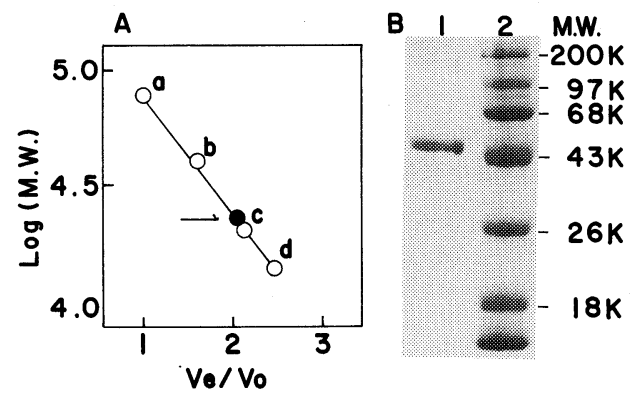

FIG. 2. Determination of the Molecular Weight of Methylglyoxal Reductase by Gel Filtration (A) and SDS/Polyacrylamide Gel Electrophoresis.

[A]: The procedures for gel filtration were described under Materials AND Methods. $V e$ and $V o$ are the elution volume of proteins and the void volume of the column, respectively. The standard proteins used were: a, pyruvate kinase (MW 57,000); b, glyceraldehyde 3-phosphate dehydrogenase (MW 36,000); c, trypsin (MW 23,000); and d, lysozyme (MW 14,300). The elution position of methylglyoxal reductase is indicated by an arrow.

[B]: SDS/polyacrylamide gel electrophoresis was performed by the method of Laemmli. ${ }^{10)}$ Lane 1, methylglyoxal reductase; lane 2, standard proteins (from the top: myosin (H-chain), phosphorylase B, bovine serum albumin, ovalbumin, $\alpha$-chymotrypsinogen, $\quad \beta$-lactoglobulin and lysozyme).

(2) Substrate specificity. The enzyme required NADPH for the reduction of 2-oxoaldehydes. NADH could substitute for NADPH, but the efficiency was lower (Table III). The enzyme was active on various 2oxoaldehydes (glyoxal, methylglyoxal, phenylglyoxal and 4,5-dioxovalerate) and some al- 
Table III. Substrate Specificity of MethylglyoXal ReDuctase

\begin{tabular}{llc}
\hline $\begin{array}{l}\text { Substrate } \\
(10 \mathrm{~mm})\end{array}$ & $\begin{array}{c}\text { Cofactor } \\
(0.1 \mathrm{mM})\end{array}$ & $\begin{array}{c}\text { Relative } \\
\text { activity } \\
(\%)\end{array}$ \\
\hline Glyoxal & NADPH & 83.1 \\
Methylglyoxal & NAD & 0 \\
& NADH & 42.2 \\
& NADP & 0 \\
4,5-Dioxovalerate & NADPH & 100 \\
& NADH & 83.6 \\
Phenylglyoxal & NADPH & 165 \\
Glycolaldehyde & NADPH & 60.1 \\
DL-Glyceraldehyde & NADPH & 38.9 \\
Propionaldehyde & NADPH & 3.8 \\
Acetaldehyde & NADPH & 3.0 \\
Formaldehyde & NADPH & 1.0 \\
Acetol & NADPH & 0 \\
& NADPH & 0 \\
\hline
\end{tabular}

The reaction was carried out as described under Materials AND Methods using various substrates and cofactors at the indicated concentrations. The activity of the enzyme for methylglyoxal in the presence of NADPH was taken as $100 \%$.

dehydes (glycolaldehyde, D,L-glyceraldehyde, propionaldehyde and acetaldehyde) (Table III).

(3) $\mathrm{Km}$ values. The $\mathrm{Km}$ values of the enzyme for methylglyoxal and 4,5-dioxovalerate were calculated to be $4.0 \mathrm{~mm}$ and $0.2 \mathrm{~mm}$, respectively, from Lineweaver-Burk plots. Likewise, the $K m$ values for NADPH and NADH were determined to be $2.8 \mu \mathrm{M}$ and $4.3 \mu \mathrm{M}$, respectively.

(4) Effects of metal ions and others. The enzyme required no metal ions for its activity. $\mathrm{Cu}^{2+}(5.0 \mathrm{~mm}), \mathrm{Hg}^{2+}(0.1 \mathrm{~mm})$ and $p$-chloromercuribenzoate $(0.1 \mathrm{mM})$ completely inhibited the enzyme activity. $\mathrm{Zn}^{2+}, \mathrm{Ni}^{2+}$ and $\mathrm{Co}^{2+}$ also inhibited the activity of the enzyme, the inhibition being around $40 \%$ at $5.0 \mathrm{~mm}$ of each. Glutathione, dithiothreitol and 2-mercaptoethanol slightly activated $(20 \sim 30 \%)$ the enzyme at $1.0 \mathrm{~mm}$. $N$-Ethylmaleimide, acetamide and iodoacetamide slightly inhibited $(5 \sim 10 \%)$ the activity of the enzyme at $5.0 \mathrm{~mm}$. Chelators (EDTA and 8-hydroxyquinoline) showed no appreciable effects on the enzyme activity.

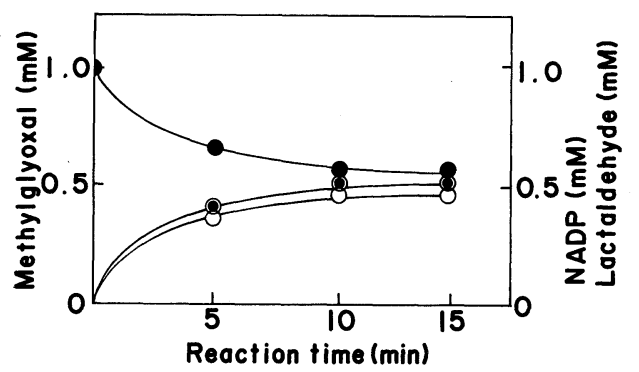

FIG. 3. Stoichiometry of the Methylglyoxal Reductase Reaction.

The methylglyoxal reductase reaction was carried out in a mixture $(2.0 \mathrm{ml})$ containing $1.0 \mathrm{~mm}$ methylglyoxal, $0.5 \mathrm{~mm}$ $\mathrm{NADPH}, 100 \mathrm{~mm}$ sodium acetate buffer $(\mathrm{pH} 6.5)$ and $20 \mu \mathrm{g} / \mathrm{ml}$ enzyme at $25^{\circ} \mathrm{C}$. At the prescribed times, $0.3 \mathrm{ml}$ of the mixture was taken and the concentration of substrates and products were determined. Methylglyoxal and lactaldehyde were determined enzymatically using glyoxalase I and lactaldehyde dehydrogenase, respectively. The procedures for the purification of lactaldehyde dehydrogenase are described in our previous paper. ${ }^{2)}$

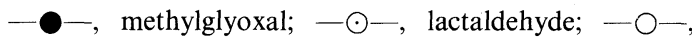
NADP.

(5) Stoichiometry of the methylglyoxal reductase reaction. The stoichiometry of the methylglyoxal reductase reaction was investigated (Fig. 3). The amount of NADPH oxidized was nearly proportional to that of methylglyoxal consumed, when the remaining methylglyoxal in the reaction mixture was determined enzymatically using glyoxalase I. The reduction product of methylglyoxal was a substrate of NAD-linkèd lactaldehyde dehydrogenase, which was partially purified from Saccharomyces cerevisiae DKD-5D-H by the method described previously. ${ }^{2)}$ The amount of lactaldehyde (or NADH) formed was also proportional to that of NADP formed or methylglyoxal consumed (Fig. 3).

\section{DISCUSSION}

No extensive studies on the physiological functions of 2-oxoaldehydes have been performed, though the compound have been reported to function in cell division, and protein and nucleic acid syntheses. ${ }^{11)}$ Through a study on the metabolism of typical biological 2- 
oxoaldehydes, methylglyoxal and 3,4-dioxovalerate, in yeast cells, we obtained evidence that these compounds were converted to lactaldehyde by a reducing enzyme, which we called methylglyoxal reductase. ${ }^{1)}$ The enzyme was purified, characterized and shown to be different from the goat liver methylglyoxal reductase isolated recently by Ray and Ray. ${ }^{3)}$ Our interest was, therefore, focussed on the systematic comparison of the properties of methylglyoxal reductases among bacterial, yeast and mammalian systems.

For the selection of a suitable strain and to comparison of the enzyme activities among bacterial cells, the distribution of methylglyoxal reductase activity and other enzyme activities responsible for 2-oxoaldehyde metabolism was investigated (Table I). Such enzyme activities were detected in all the strains tested. Although the data are not shown here, such enzyme activities were also found in rat tissues at levels comparable to those in microbial cells, indicating that the same 2-oxoaldehyde-metabolizing routes, which we have already detected in yeast cells, ${ }^{7,12)}$ function in microbial and mammalian systems.

Methylglyoxal reductase was purified from $E$. coli cells. Contrary to in the case of yeast ${ }^{1)}$ and goat liver, ${ }^{3)}$ the $E$. coli cells contained two kinds of methylglyoxal reductases (Peaks I and II enzymes) (Figs. 1C and D). Judging from their behavior on column chromatographies (Fig. 1), these two enzymes may exist as associated and dissociated forms, depending on the $\mathrm{pH}$ in cells. The molecular weight of the purified E. coli methylglyoxal reductase (Peak II enzyme) was similar to that of the yeast enzyme, but was different from that of the goat liver reductase. The $E$. coli and yeast reductases are both monomers with molecular weights of around 43,000, whereas the goat liver enzyme has been reported to be a dimer with a molecular weight of 89,000 . The $E$. coli and goat liver reductases were, however, different from the yeast enzyme in both cofactor requirement and substrate specificity. The $E$. coli and goat liver enzymes utilized both NADH and NADPH for the reduction of 2- oxoaldehydes and some aldehydes, though the yeast enzyme was specific for both NADPH and 2-oxoaldehydes. Thus, the properties of methylglyoxal reductases were shown to vary depending on the source of the enzyme.

The physiological role of methylglyoxal reductase in bacterial, yeast and mammalian systems is not yet clear, though a study on the enzyme in yeast cells suggested that the enzyme functioned in the detoxification of methylglyoxal and 4,5-dioxovalerate. ${ }^{1,13)}$ The low $K m$ value of $E$. coli methylglyoxal reductase for 4,5-dioxovalerate may suggest that the reductase, in combination with glyoxalase I, may function in the regulation of the synthesis of porphyrin compounds such as vitamin $\mathrm{B}_{12}$, since 4,5-dioxovalerate is an intermediate in the synthesis of such compounds. ${ }^{4,14)}$ A physiological study on the role of the methylglyoxal reductase is in progress.

Acknowledgment. The work was supported in part by a Grant-in-Aid for Scientific Research (No. 61560120) for the Ministry of Education, Science and Culture of Japan.

\section{REFERENCES}

1) K. Murata, Y. Fukuda, M. Shimosaka, K. Watanabe, T. Saikusa and A. Kimura, Eur. J. Biochem., 151, 631 (1985).

2) Y. Inoue, K. Watanabe, M. Shimosaka, T. Saikusa, Y. Fukuda, K. Murata and A. Kimura, Eur. J. Biochem., 153, 243 (1985).

3) M. Ray and S. Ray, Biochim. Biophys. Acta, 802, 119 (1984).

4) L. Varticovski, J. P. Kushner and B. F. Burnham, J. Biol. Chem., 255, 3742 (1980).

5) E. Huff and H. Rudney, J. Biol. Chem., 234, 1060 (1959).

6) K. Murata, T. Saikusa, K. Watanabe, Y. Inoue, Y. Fukuda, M. Shimosaka and A. Kimura, Agric. Biol. Chem., 50, 2381 (1986).

7) K. Murata, Y. Inoue, K. Watanabe, Y. Fukuda, T. Saikusa, M. Shimosaka and A. Kimura, Agric. Biol. Chem., 50, 135 (1986).

8) Rhee Hae-ik, K. Watanabe, K. Murata and A. Kimura, Agric. Biol. Chem., 51, 1059 (1987).

9) O. H. Lowry, N. J. Rosebrough, A. L. Farr and R. J. Randall, J. Biol. Chem., 193, 265 (1951).

10) U. K. Laemmli, Nature, 227, 135 (1979).

11) A. Szent-Györgyi, Science, 149, 34 (1965).

12) K. Murata, Y. Inoue, T. Saikusa, K. Watanabe, Y. Fukuda, M. Shimosaka and A. Kimura, J. Ferment. 
Technol., 63, 1 (1986).

13) K. Murata and A. Kimura, Protein, Nucleic Acid and Enzyme, 31, 1010 (1986).
14) T. Jerzykowski, R. Winter and W. Matuszewski, Biochem. J., 135, 713 (1973). 